Nuraini, A. · Sumadi · M. Kadapi · A. Wahyudin · D. Ruswandi · M. N. Anindya

\title{
Evaluasi ketahanan simpan enam belas genotip benih jagung hibrida Unpad pada periode simpan empat bulan
}

\section{Evaluation of seed longevity of 16 Unpad hybrid corn genotypes on four months storage period}

\author{
Diterima : 13 Februari 2018/Disetujui : 13 Maret 2018 / Dipublikasikan : 31 Maret 2018 \\ CDepartment of Crop Science, Padjadjaran University
}

\begin{abstract}
Seed storage is a post-harvest activity that is done to maintain the seed quality before planting. The problem often encountered in seed storage is the rapid reduction of seed quality in short period of time. Seed storability is important to maintain seed quality in good condition. The aim of this research was to find out the best seed storability of 16 genotypes of UNPAD Hybrid Maize Seeds after 4 months storage period. This research was done by identificating best seed storability after some storage period of single hybrid maize seed, namely, DR (Downey Resistance), BR, MDR (mutant of DR), and MBR (mutant of BR) which are a collection of Maize Development Team Plant Breedung Laboratory Faculty of Agriculture Universitas Padjadjaran. This research was conducted from October 2016 until February 2017 at Seed Technology Laboratory Faculty of Agriculture Universitas Padjadjaran. Completely Randomized Design was used and repeated two times. Data were tabulated and analyzed using the F test, while to test the significant difference further were using Scott Knott test level of $5 \%$. The result showed that there is significant difference in electrical conductivity value, 1000 grain weight, seed germination capacity, vigor index, seed growth simultaneously, and normal seedling dry weight after 4 months storage period. MDR 18.5.1, DR 17, 4BR 157, 4MDR 14.1.1 were the best genotype on seed storability after 4 months storage period.
\end{abstract}

Keywords : maize, genotypes, seed storability, storage period

\footnotetext{
Dikomunikasikan oleh Erni Suminar

Nuraini, A. · Sumadi · M. Kadapi · A. Wahyudin · D.

Ruswandi · M. N. Anindya

Program Studi Agroteknologi Fakultas Pertanian UNPAD

Korespondensi: anne.nuraini@unpad.ac.id
}

Sari. Penyimpanan benih merupakan kegiatan pascapanen yang dilakukan untuk mempertahankan mutu benih hingga benih tersebut siap ditanam. Permasalahan yang sering dihadapi pada penyimpanan benih yaitu penurunan mutu benih secara cepat dalam periode yang belum terlalu lama. Tujuan dari penelitian ini adalah untuk mengetahui ketahanan simpan 16 genotip benih jagung hibrida UNPAD yang terbaik setelah periode simpan empat bulan. Penelitian ini dilakukan dengan mengidentifikasi ketahanan simpan terbaik setelah beberapa periode simpan dari genotip benih jagung hibrida tunggal, yaitu genotip DR (Downey Resistance), BR, MDR (mutan DR), dan MBR (mutan BR) yang merupakan koleksi Tim Pengembangan Jagung Laboratorium Pemuliaan Tanaman Fakultas Pertanian Universitas Padjadjaran. Penelitian dilakukan pada bulan Oktober 2016 sampai Februari 2017 di Labora-torium Teknologi Benih Fakultas Pertanian Universitas Padjadjaran. Penelitian ini dilakukan dengan menggunakan Rancangan Acak Leng-kap (RAL) 2 ulangan. Data dianalisis mengguna-kan uji F, sedangkan perbedaan yang signifikan antar perlakuan digunakan uji Scott Knott pada taraf nyata $5 \%$. Hasil penelitian menunjukkan terdapat perbedaan yang signifikan pada parameter daya hantar listrik, bobot 100 butir, daya berkecambah, indeks vigor, keserempakan tumbuh, serta bobot kering kecambah normal setelah periode simpan 4 bulan. Genotip MDR 18.5.1, DR 17, 4BR 157, 4MDR 14.1.1 merupakan genotip yang memiliki ketahanan simpan setelah periode simpan 4 bulan.

Kata kunci: jagung, genotip, ketahanan simpan, periode simpan 


\section{Pendahuluan}

Jagung merupakan sumber pangan karena memiliki kedudukan sebagai sumber utama bahan pangan dengan kandungan karbohidrat yang tinggi setelah beras.. Kebutuhan jagung nasional dari tahun ke tahun terus meningkat. Peningkatan kebutuhan jagung di Indonesia sejalan dengan peningkatan jumlah penduduk dan pertumbuhan industri, sehingga perlu adanya peningkatan produksi jagung untuk dapat memenuhi kebutuhan jagung di Indonesia (Zubachtirodin dkk., 2005). Menurut Pusat Data dan Sistem Informasi Pertanian Kementerian Pertanian (2016) pada tahun 2017 dan 2018 proyeksi permintaan jagung untuk konsumsi rumah tangga masing-masing sebesar 1,58 $\mathrm{kg} / \mathrm{kapita} /$ tahun dan $1,51 \mathrm{~kg} / \mathrm{kapita} / \mathrm{tahun}$, sehingga total kebutuhan jagung untuk konsumsi langsung pada tahun 2016, 2017 dan 2018 masing-masing diramalkan sebesar 425 ribu ton, 412 ribu ton dan 400 ribu ton.

Benih merupakan salah satu komponen penting dalam peningkatan hasil jagung. Banyaknya peran penting dari jagung mendorong adanya ketersediaan benih bermutu dan varietas unggul baru yang dapat memenuhi kuantitas, kualitas, dan kontinyuitas (Direktorat Perbenihan Tanaman Pangan, 2005). Penggunaan varietas unggul dengan mutu yang baik adalah faktor utama keberhasilan budidaya tanaman (Copeland \& McDonald, 2004). Hal tersebut mendorong adanya perakitan kultivar hibrida dengan spesifik wilayah untuk terus meningkatkan produksi jagung dan memberikan untung terhadap petani dalam penanaman kultivar hibrida.

Ketersediaan benih dengan mutu benih yang dipertahankan merupakan suatu kendala yang dihadapi pada permintaan dan kebutuhan jagung yang tinggi. Penyimpanan benih merupakan suatu kegiatan penanganan pasca panen yang dilakukan untuk mempertahankan mutu dan kualitas benih dalam keadaan dan kondisi yang baik, sampai benih tersebut sampai di tangan petani dan siap ditanam di lapangan (Kuswendi dkk., 2009). Permasalahan yang sering dihadapi pada penyimpanan yaitu penurunan mutu benih yang terjadi secara cepat, sedangkan masa simpan dari benih tersebut belum terlalu lama..

Menurut Elia dkk. (2009), untuk mengetahui mutu fisik benih dapat dilakukan pengujian kadar air benih dan bobot 1000 butir.
Untuk mengetahui mutu fisiologis benih dapat dilakukan pengujian viabilitas dengan daya berkecambah benih, pengujian uji vigor dengan mengamati indeks vigor, kecepatan tumbuh, dan daya hantar listrik (Sadjad, 1993). Kadar air merupakan faktor dominan yang mempengaruhi mutu benih. Benih jagung yang disimpan pada kadar air 8\% dan suhu yang rendah memiliki ketahanan yang lebih tinggi terhadap serangan jamur sehingga daya berkecambah dan indeks vigornya tetap tinggi (Niaz dkk., 2011). Viabilitas dan vigor yang menurun dapat pula diketahui melalui nilai daya hantar listrik yang semakin tinggi seiring dengan lamanya periode simpan (Koes dan Arief, 2010).

Ketahanan simpan suatu galur atau genotip dapat diketahui melalui identifikasi mutu fisik dan fisiologi benih (Elia dkk., 2009). Kandungan protein yang berbeda berpengaruh terhadap mutu atau kualitas dan kemampuan daya simpan pada masing-masing genotip. Demikian pula dengan ukuran dan bentuk benih yang dapat mempengaruhi mutu dan kualitas serta ketahanan simpan benih. Ukuran benih yang lebih besar menghasilkan persentase berkecambah, bobot segar kecambah, bobot kering kecambah, dan bobot 1000 butir yang lebih tinggi (Sadeghi dkk., 2011).

Penurunan mutu benih dapat menimbulkan perubahan secara menyeluruh baik fisik, fisiologis, maupun biokimia sehingga viabilitas benih menurun (Umar, 2012). Proses penuaan atau kemunduran vigor benih secara fisiologis dilihat dari terdapatnya penurunan daya berkecambah, peningkatan jumlah kecambah abnormal, terhambatnya pertumbuhan dan perkembangan tanaman, penurunan perkecambahan, dan peningkatan kepekaan benih terhadap lingkungan ekstrim dapat menurunkan produksi tanaman (Copeland \& McDonald, 2004).

Elia dkk. (2009) mengidentifikasi mutu fisik dan fisiologis benih jagung yang disimpan dalam dua kondisi yang berbeda setelah periode simpan pada ruang terkendali yaitu ruangan dengan suhu $18^{\circ} \mathrm{C}$ dan $\mathrm{RH} 45^{\circ} \mathrm{C}$ dan ruang tidak terkendali tanpa pengaturan suhu $\left(22-25^{\circ} \mathrm{C}\right)$ maupun $\mathrm{RH}\left(75-85^{\circ} \mathrm{C}\right)$. Percobaan tersebut menunjukkan hasil bahwa ruangan terkendali mempertahankan kualitas benih jagung setelah periode simpan 3 bulan. Deteriorasi lanjut terjadi pada ruangan tidak terkendali, berbeda dengan ruang terkendali yang deteriorasinya dapat dihambat.

Penelitian Rahmawati dkk. (2005) menun- 
jukkan bahwa benih yang berukuran besar (S1), sedang (S2), dan kecil (S3) dengan kadar air penyimpanan $9-13 \%$ selama 6 bulan, mengalami penurunan daya berkecambah pada kadar air $13,5 \%$ menjadi $83,3 \%-86,7 \%$. Semakin tinggi kadar air dalam benih, semakin cepat respirasi dan semakin banyak $\mathrm{CO}_{2}$, air dan panas yang dihasilkan saat benih disimpan. Kadar air, suhu, dan kelembaban yang tinggi dapat mempercepat kerusakan benih (Thahir dkk., 1988). Ukuran benih berhubungan dengan vigor benih. Benih dengan ukuran lebih besar memiliki vigor yang lebih baik. Parameter perkecambahan berhubungan dengan bobot benih dan ukuran benih. Ukuran benih yang lebih besar menghasilkan persentase berkecambah, bobot segar kecambah, bobot kering kecambah, dan bobot 1000 butir yang lebih tinggi (Sadeghi dkk., 2011 dalam Ambika dkk., 2014). Pada genotip tanaman lentil (Lens culinaris Medik), parameter perkecambahan menunjukkan benih dengan ukuran dan bobot yang lebih besar menghasilkan perkecambahan yang lebih baik dibandingkan dengan benih yang lebih kecil (Hojjat, 2011).

Enam belas genotip jagung yang akan diuji dalam penelitian ini memiliki latar belakang genetik yang berbeda sehingga akan memberi respon yang berbeda terhadap ketahanan simpan masing-masing genotip, maka dari itu perlu dilakukan evaluasi untuk mengetahui ketahanan simpan benih 16 genotip jagung hibrida hasil pemuliaan tim jagung UNPAD yang dikordinir Dedi Ruswandi sehingga dapat diketahui genotip mana yang mempunyai ketahanan simpan yang paling baik.

Berdasarkan uraian di atas, maka perlu dilakukan evaluasi terhadap karakter fisik dan fisiologis pada genotip jagung hibrida UNPAD koleksi tim Laboratorium Teknologi Benih dan Pemuliaan Tanaman Fakultas Pertanian Universitas Padjadjaran setelah disimpan 4 bulan, sebelum jagung-jagung tersebut dilepas sebagai tetua varietas hibrida baru. Pada penelitian ini digunakan benih enam belas genotip jagung hibrida UNPAD hasil pemuliaan Dedi Ruswandi terdiri dari genotip DR, MDR, BR, dan MBR yang memiliki karakter unggul antara lain produktivitas tinggi, memiliki kandungan protein yang tinggi, tahan terhadap penyakit bulai, dan memiliki umur genjah.

Hasil penelitian Yuwariah dkk. (2017) menunjukkan bahwa karakter pertumbuhan, komponen hasil dan hasil bobot biji pipilan kering jagung hibrida Unpad dalam pola tanam tumpangsari dengan kedelai dan tumpangsari dengan padi hitam (Azizah dkk., 2017) bervariasi diantara genotipe, sehingga dari percobaan ini diduga dari 16 genotipe jagung yang diuji juga akan mempunyai daya simpan yang berbeda dan ada genotipe-genotipe yang mempunyai daya simpan yang terbaik. Tujuan penelitian ini adalah untuk mendapatkan genotip jagung hibrida Unpad yang memiliki daya simpan terbaik setelah periode 4 bulan penyimpanan.

\section{Bahan dan Metode}

Percobaan dilakukan di Laboraturium Teknologi Benih dan Pemuliaan Tanaman Departemen Budidaya Pertanian Fakultas Pertanian Universitas Padjadjaran mulai dari bulan Oktober 2016 sampai Februari 2017.

Bahan yang digunakan dalam percobaan ini adalah benih 16 genotip jagung hibrida Unpad hasil pemuliaan Dedi Ruswandi (yang dipanen pada bulan Agustus 2016 dan disimpan di gudang Kebun Arjasari Bandung), kertas merang dan aquades. Alat-alat yang digunakan dalam penelitian ini adalah thermometer dan higrometer, keranjang plastik, kain kassa 30×30 $\mathrm{cm}$, germinator, timbangan analitik, oven, conductivity meter, germinator, plastik, tali rafia, label, pinset, hand sprayer, gelas ukur $250 \mathrm{ml}$, desikator, dan alat tulis.

Metode yang digunakan dalam penelitian ini adalah menggunakan metode eksperimen Rancangan Acak Lengkap (RAL) yang diulang dua kali. Perlakuan yang diuji dalam percobaan ini adalah benih enam belas genotip jagung hibrida UNPAD yaitu DR, MDR, BR, dan MBR pada periode simpan dua dan empat bulan. Data yang diperoleh dianalisis secara statistik dengan uji $\mathrm{F}$ dilanjutkan dengan uji perbedaan nilai rata-rata yaitu Uji Scott Knott pada taraf 5\%. Analisis data hasil pengamatan dilakukan dengan menggunakan software SPSS 17.0.

Benih dipanen pada bulan Agustus 2016 yang disimpan sementara menggunakan karung di gudang Kebun Arjasari Bandung. Setelah itu benih dikeringkan dan dipipil. Benih disimpan dalam ruang simpan suhu kamar pada wadah berupa kain kassa dan disimpan dalam keranjang plastik di Laboratorium Teknologi Benih dan Pemuliaaan Tanaman Departemen Budidaya Tanaman Fakultas Pertanian Universitas 
Padjadjaran. Benih disimpan selama 4 bulan

Pengamatan dilakukan terhadap : kadar air benih (\%), daya hantar listrik, $(\mu \mathrm{S} / \mathrm{g}),(\mathrm{g})$, daya berkecambah (\%), Indeks vigor, keserempakan tumbuh dan bobot kering kecambah normal setelah disimpan 4 bulan.

\section{Hasil dan Pembahasan}

Hasil percobaan menunjukkan bahwa setelah periode simpan 4 bulan daya hantar listrik, daya berkecambah, indeks vigor, keserempakan tumbuh dan bobot kering kecambah berbeda diatara 16 genotip seperti terlihat pada Tabel 1.

Kadar air benih. Kadar air menunjukkan tingkat kekeringan benih. Menurut Pramesti dan Syamsudin (2015) kadar air benih berpengaruh terhadap daya simpan benih dan secara tidak langsung juga berpengaruh terhadap serangan hama Sithopilus zeamais. Kadar air ke-16 genotip yang diuji tidak menunjukkan perbedaan yang nyata. Benih memiliki sifat higroskopis, dimana kadar air pada benih akan selalu melakukan keseimbangan dengan lingkungan sekitar, tercapainya keseimbangan tersebut akan terjadi apabila tidak ada lagi uap air yang bergerak dari udara ke benih atau sebaliknya dari benih ke udara (Justice \& Bass, 1990, Heri Suryanto, 2013).

Salah satu faktor yang memungkinkan benih mengabsorbsi air dari lingkungannya adalah komposisi kimia benih (Justice \& Bass, 1990). Biji jagung mengandung karbohidrat 70$75 \%$, protein 11-12 \%, dan lemak 5-9 \% (Bewley \& Black, 1978). Kelembaban udara memiliki kaitan yang erat dengan suhu temperatur yang menentukan kemampuan benih untuk bertahan pada periode penyimpanan. Komponen karbohidrat dan protein cukup higroskopis, apabila benih disimpan pada ruang terbuka (tidak kedap udara), maka kadar air selalu seimbang dengan kelembaban relatif (RH) di sekitarnya.

Kadar air yang terlalu tinggi dapat mempersingkat kemampuan benih dalam periode simpan dan mempercepat laju kemunduran benih atau deteriorasi. Pada kelembaban yang tinggi, enzim-enzim semakin aktif yang dapat mengakibatkan terjadinya proses perombakan bahan cadangan makanan yang ada di dalam biji. Kadar air yang tinggi dapat meningkatkan dan memicu perkembangan aktivitas mikro-organisme, seperti cendawan (Naning Yuniarti dkk., 2013) dan hama gudang (Singgih Kurniawan dkk., 2008). Adanya serangan cendawan dan hama gudang ini menyebabkan kerusakan benih sehingga dapat merusak kemampuan benih untuk berkecambah.

Daya Hantar Listrik Benih. Daya hantar listrik merupakan suatu pengujian yang dapat dilakukan untuk mengetahui tingkat kemunduran benih. Semakin besar nilai daya hantar

Tabel 1. Kadar Air, Daya Hantar Listrik, Daya Berkecambah, Indeks Vigor, Keserempakan Tumbuh Benih dan Bobot Kering Kecambah 16 Genotipe Jagung Unpad setelah Penyimpanan Empat Bulan

\begin{tabular}{|c|c|c|c|c|c|c|c|}
\hline & Genotipe & $\begin{array}{c}\text { Kadar Air } \\
(\%)\end{array}$ & $\begin{array}{c}\text { DHL } \\
(\mu \mathrm{S} / \mathrm{g})\end{array}$ & $\begin{array}{l}\text { DB } \\
(\%)\end{array}$ & IV & $\begin{array}{l}\text { KT } \\
(\%)\end{array}$ & $\begin{array}{c}\text { BKKN } \\
(\mathrm{g})\end{array}$ \\
\hline$\overline{1}$ & DR 17 & $15,29 a$ & $0,075 \mathrm{c}$ & $86,25 \mathrm{a}$ & $7,32 \mathrm{a}$ & $32,50 \mathrm{~b}$ & $0,17 \mathrm{a}$ \\
\hline 2 & DR 18 & $15,39 \mathrm{a}$ & $0,095 \mathrm{~b}$ & $70,00 \mathrm{~b}$ & $6,45 b$ & $42,50 \mathrm{a}$ & $0,12 \mathrm{~b}$ \\
\hline 3 & DR 20 & $15,59 \mathrm{a}$ & $0,125 \mathrm{a}$ & $70,00 \mathrm{~b}$ & $6,40 \mathrm{~b}$ & $43,75 a$ & $0,11 \mathrm{~b}$ \\
\hline 4 & BR 157 & $15,21 \mathrm{a}$ & $0,055 \mathrm{c}$ & $81,25 \mathrm{a}$ & $7,55 \mathrm{a}$ & $55,00 \mathrm{a}$ & $0,15 \mathrm{~b}$ \\
\hline 5 & MDR 10.2.2 & 16,27 a & $0,110 \mathrm{a}$ & $72,50 \mathrm{~b}$ & $6,58 \mathrm{~b}$ & $40,00 \mathrm{a}$ & $0,14 \mathrm{~b}$ \\
\hline 6 & MDR 12.3.1 & $15,89 \mathrm{a}$ & $0,050 \mathrm{c}$ & $73,75 \mathrm{~b}$ & $6,75 \mathrm{~b}$ & $45,00 \mathrm{a}$ & $0,18 \mathrm{a}$ \\
\hline 7 & MDR 12.3.2 & $15,92 \mathrm{a}$ & $0,095 \mathrm{~b}$ & $75,00 \mathrm{~b}$ & $6,59 \mathrm{~b}$ & $33,75 \mathrm{~b}$ & $0,22 \mathrm{a}$ \\
\hline 8 & MDR 14.1.1 & $15,96 \mathrm{a}$ & $0,070 \mathrm{c}$ & $80,00 \mathrm{a}$ & $7,06 \mathrm{a}$ & $33,75 \mathrm{~b}$ & $0,19 \mathrm{a}$ \\
\hline 9 & MDR 14.2.1 & $15,71 \mathrm{a}$ & $0,090 \mathrm{~b}$ & $73,75 \mathrm{~b}$ & $6,44 b$ & $33,75 \mathrm{~b}$ & $0,12 \mathrm{~b}$ \\
\hline 10 & MDR 14.3.1 & $15,53 \mathrm{a}$ & $0,095 \mathrm{~b}$ & $67,50 \mathrm{~b}$ & $6,35 \mathrm{~b}$ & $47,50 \mathrm{a}$ & $0,11 \mathrm{~b}$ \\
\hline 11 & MDR 16.5.15 & $15,89 \mathrm{a}$ & $0,050 \mathrm{c}$ & $81,25 \mathrm{a}$ & $6,81 b$ & $18,75 \mathrm{c}$ & $0,14 \mathrm{~b}$ \\
\hline 12 & MDR 16.6.14 & $15,66 \mathrm{a}$ & $0,085 \mathrm{~b}$ & $71,25 \mathrm{~b}$ & $6,63 b$ & $46,25 \mathrm{a}$ & $0,18 \mathrm{a}$ \\
\hline 13 & MDR 18.5.1 & $15,02 \mathrm{a}$ & $0,065 \mathrm{c}$ & $87,50 \mathrm{a}$ & $7,98 \mathrm{a}$ & $53,75 \mathrm{a}$ & $0,18 \mathrm{a}$ \\
\hline 14 & MBR 153.11.1 & $15,69 \mathrm{a}$ & $0,075 \mathrm{c}$ & $71,25 \mathrm{~b}$ & $5,65 c$ & $15,00 \mathrm{c}$ & $0,16 \mathrm{~b}$ \\
\hline 15 & MBR 153.13.1 & $15,38 \mathrm{a}$ & $0,110 \mathrm{a}$ & $72,50 \mathrm{~b}$ & $5,88 \mathrm{c}$ & $16,25 \mathrm{c}$ & $0,14 \mathrm{~b}$ \\
\hline 16 & MBR 153.15.1 & $15,84 \mathrm{a}$ & $0,130 \mathrm{a}$ & $68,75 \mathrm{~b}$ & $5,84 \mathrm{c}$ & $26,25 \mathrm{~b}$ & $0,14 \mathrm{~b}$ \\
\hline
\end{tabular}

Keterangan: Angka yang diikuti oleh huruf yang sama tidak berbeda nyata berdasarkan uji Scott Knott pada taraf nyata $5 \%$.

$\mathrm{DHL}=$ Daya Hantar Listrik, DB = Daya Berkecambah, IV = Indeks Vigor, KT = Keserempakan Tumbuh dan BKKN = Bobot Kering Kecambah GBHFTNG VB 
listrik maka semakin rendah vigor benih (Copeland \& McDonald, 2004). Kebocoran benih akan dapat menghilangkan bahan-bahan yang dikandung benih tersebut lebih banyak daripada benih dengan kualitas yang lebih baik (Fessel dkk., 2006). Indikasi biokimia kemunduran benih dicirikan dengan adanya penurunan aktivitas enzim, penurunan cadangan makanan, dan meningkatnya nilai konduktivitas (daya hantar listrik) (Tatipata, 2004).

Berdasarkan hasil uji daya hantar listrik (Tabel 1), benih yang memiliki daya hantar listrik tertinggi yaitu pada genotip DR 20, MDR 10.2.2, MBR 153.13.1 dan MBR 153.15.1. Genotip yang diuji memiliki keragaman nilai bocoran membran tersebut. Perbedaan nilai daya hantar listrik yang berbeda pada masing-masing genotip kemungkinan dikarenakan oleh karakter genetik pada masing-masing genotip yang berbeda yang memungkinkan benih memiliki tingkat permeabelitas kulit yang berbeda pula.

Daya berkecambah dengan daya hantar listrik memiliki hubungan yang berbanding terbalik. Semakin tinggi nilai daya hantar listrik, maka nilai viabilitasnya semakin menurun. Nilai daya hantar listrik yang tinggi menunjukkan kebocoran metabolit benih yang tinggi yang dapat menurunkan kualitas dari benih (Widodo dkk., 2013). Peningkatan tersebut disebabkan karena suhu, kadar air, dan juga lama periode simpan yang menyebabkan tingkat kerusakan membran sel, yang ditunjukan adanya konduktivitas yang semakin meningkat. Suhu ruang simpan dan periode simpan mempengaruhi jumlah elektrolit yang dihasilkan dari uji daya hantar listrik (Vieira dkk., 2008).

Semakin tinggi hasil uji daya hantar listrik, semakin rendah vigor dari benih tersebut. Hal tersebut dikarenakan peningkatan nilai daya hantar listrik disebabkan oleh adanya kebocoran elektrolit yang permeabilitas membran benihnya meningkat (Matthew \& Powell, 2006). Penurunan integritas membran terjadi diakibatkan oleh adanya kerusakan fosfolipid dan protein sebagai komponen utama penyusun membran sel yang menyebabkan kebocoran larutan dalam benih (Tatipata, 2010). Benih yang bervigor rendah diketahui memiliki penurunan integritas membran sel sebagai ketidakaturan membran sel yang menyebabkan membran sel menjadi rusak. Kerusakan membran sel ini berimbas kepada kebocoran hasil metabolism dalam benih yang semakin tinggi (Widodo dkk., 2013).

Daya berkecambah benih setelah penyim- panan. Benih yang memiliki viabilitas tinggi lebih mempunyai ketahanan simpan yang lebih tinggi dibandingkan dengan benih yang memiliki viabilitas yang lebih rendah sehingga benih dapat disimpan pada periode waktu yang lebih lama (Sutopo, 2004). Benih yang memiliki persentase daya berkecambah paling tinggi adalah DR 17, BR 157, MDR 14.1.1, MDR 16.5.15, dan MDR 18.5.1. Daya berkecambah mengalami penurunan seiring dengan lamanya periode simpan.

Pada 4 bulan setelah penyimpanan, nilai daya berkecambah mengalami penurunan yang diduga diakibatkan oleh terjadinya deteriorasi. Terjadinya kemunduran benih atau deteriorasi dicirikan oleh adanya penurunan daya berkecambah benih. Benih yang disimpan pada periode yang lama, kadar air tinggi dan penempatan yang kurang memadai mempercepat deteriorasi yang ditandai dengan adanya daya berkecambah yang semakin menurun (Widodo dkk., 2013). Penurunan daya berkecambah benih diduga terjadi akibat hilangnya cadangan makanan di dalam benih secara cepat diakibatkan adanya kadar air yang tinggi. Kadar air yang terlalu tinggi pada saat penyimpanan akan memicu peningkatan proses respirasi dan kegiatan enzim sehingga mendorong terjadinya perombakan cadangan makanan dalam biji yang mengakibatkan energi yang terhambur dalam bentuk panas ditambah keadaan yang lembab akan merangsang perkembangan mikroorganisme yang dapat merusak benih (Naning Yuniarti dkk., 2013).

Penurunan daya berkecambah juga disebabkan oleh lamanya periode penyimpanan benih tersebut. Daya berkecambah akan menurun seiring dengan menigkatnya periode simpan atau lama penyimpanan benih. Kerusakan struktur membran dapat terjadi dalam benih pada saat benih disimpan dalam waktu yang lama (Justice \& Bass, 2002). Benih dengan kualitas yang tinggi dapat memiliki ketahanan simpan yang lebih tinggi dibandingkan dengan benih dengan kualitas yang rendah (Kartahadimaja dkk., 2013). Laju respirasi yang cepat dapat mengakibatkan perombakan cadangancadangan makanan dalam benih yang dapat menyebabkan benih mengalami kehilangan cadangan makanan sehingga benih tersebut mengalami penurunan viabilitas yang menyebabkan penurunan daya berkecambah benih.

Daya berkecambah yang menurun dapat pula disebabkan oleh adanya aktivitas mikro- 
organisme yang menyerang benih, seperti hama dan cendawan Selain itu, tejadi pula serangan cendawan pada benih saat perkecambahan. Kehadiran cendawan yang mengkontaminasi benih dapat menurunkan viabilitas benih (Singgih Kurniawan dkk., 2008). Hama yang menyerang benih jagung selama penyimpanan yaitu kumbang bubuk atau Sitophilus zeamais. Serangan hama pada populasi yang tinggi, selain mengakibatkan kerusakan benih dan susut bobot, juga meningkatkan kadar air benih sebagai hasil dari respirasi. Selain itu, tejadi pula serangan cendawan pada benih saat perkecambahan.

Adanya serangan hama gudang diduga dikarenakan oleh penggunaan kain kassa sebagai wadah penyimpanan benih. Kain kassa merupakan kemasan yang bersifat phorus dengan pori-pori besar sehingga memudahkan pertukaran udara yang memicu adanya aktivitas mikroorganisme. Hasil penelitian Sigit dkk. (2005), menunjukkan bahwa pada wadah yang kedap udara dimana suplai $\mathrm{O}_{2}$ atau penyerapan $\mathrm{O}_{2}$ dari luar sangat sulit, sehingga untuk respirasi biji maupun mikroorganisme di dalam penyimpanan akan memanfaatkan $\mathrm{O}_{2}$ yang terdapat dalam kemasan tersebut.

Indeks Vigor Benih Setelah Penyimpanan. Benih bervigor tinggi akan tumbuh lebih cepat karena benih tersebut berkecambah dalam waktu yang relatif singkat (Sadjad, dkk., 1994). Indeks vigor merupakan indicator untuk mengetahui kecepatan dan keseragaman benih dalam melakukan perkecambahan. Indeks vigor maksimum benih dapat diketahui melalui jumlah benih yang berkecambah normal pada First Day Count (FDC).

Tabel 1 menunjukkan bahwa terdapat perbedaan yang nyata terhadap indeks vigor ke16 genotip benih jagung yang diuji. Genotip yang memiliki indeks vigor yang paling tinggi adalah DR 17, BR 157, MDR 14.1.1, dan MDR 18.5.1. Kemunduran benih atau deteriorasi merupakan proses penurunan mutu benih secara berangsur-angsur dan kumulatif serta tidak dapat kembali (irreversible) dikarenakan oleh adanya perubahan fisiologis. Laju penurunan indeks vigor benih selama penyimpanan dapat dipengaruhi oleh kadar air awal benih saat dikemas tinggi, indeks vigor awal benih yang rendah, kelembaban ruang simpan yang tinggi, terdpat kerusakan benih yang diakibatkan oleh aktivitas mikroorganisme, dan kerusakan benih secara mekanis.
Penyimpanan benih menyebabkan terjadinya proses kemunduran benih secara cepat, menurunnya daya berkecambah, meningkatnya jumlah kecambah abnormal, penurunan perkecambahan di lapang (field emergence), terhambatnya pertumbuhan dan perkembangan, meningkatnya kepekaan terhadap lingkungan yang ekstrim sehingga menurunkan produktivitas di lapang (Copeland \& McDonald, 2004). Proses kemunduran benih terjadi secara cepat selama penyimpanan benih yang memiliki vigor rendah berakibat terjadinya penurunan kemampuan benih untuk daapat tumbuh, kecepatan perkecambahan benih menurun, benih semakin mudah terkena serangan hama dan penyakit, meningkatnya jumlah kecambah abnormal dan enurunkan produksi tanaman (Sadjad, 1993).

Keserempakan Tumbuh. Keserempakan tumbuh dapat diketahui melalui perhitungan kecambah normal kuat yang tumbuh pada hari ke-4. Benih normal kuat yaitu benih yang berkecambah dengan bagian yang lengkap dan penampilan perkecambahannya yang kuat (Sadjad dkk., 1999).

Berdasarkan Tabel 1, genotip benih dengan keserempakan tumbuh yang tertinggi adalah genotip BR 157. Keserempakan tumbuh tanaman yang homogen menandakan kekuatan tumbuh suatu benih yang memiliki nilai tinggi (Sadjad, 1994). Tingginya nilai keserempakan tumbuh juga menunjukkan semakin tinggi pula vigor benih tersebut (Sutopo, 2004). Menurut Lesilolo dkk. (2013), benih yang memiliki keserempakan tumbuh yang tinggi mengindikasikan vigor kekuatan tumbuh absolute yang tinggi. Hal tersebut dikarenakan benih dikatakan memiliki kekuatan tumbuh yang tinggi apabila benih tersebut menunjukkan pertum-buhan yang kuat dan serempak. Nilai keserem-pakan tumbuh yang baik berkisar antara $40-70 \%$, apabila lebih besar dari $70 \%$ dapat diartikan bahwa benih tersebut memiliki vigor kekuatan tumbuh sangat tinggi dan apabila nilai keserempakan tumbuh kurang dari $40 \%$ mengindikasikan benih-benih yang kurang vigor (Sadjad, 1993).

Bobot Kering Kecambah Normal (BKKN). Pertumbuhan benih yang baik ditandai dengan bobot kering kecambah yang baik pula. Bobot kering menunjukkan salah satu faktor pertumbuhan yang menentukan hasil dari suatu tanaman (Gardner dkk., 1991) Persediaan makanan yang terdapat di dalam biji tersebut yang dapat mendorong awal perkecambahan sebelum daun berfungsi sebagai organ fotosintesis. 
Pada parameter bobot kering kecambah normal, terdapat perbedaan yang nyata antara ke-16 genotip yang diuji. Berdasarkan data pada Tabel 1, benih yang memiliki bobot kering kecambah normal tertinggi adalah genotip DR 17, MDR 12.3.1, MDR 12.3.2, MDR 14.1.1, MDR 16.6.14, dan MDR 18.5.1. Bobot kering bibit menunjukan hasil asimilasi bersih dan mencerminkan aktivitas bibit selama pertumbuhan dan perkembangannya yaitu dalam merubah energi matahari menjadi energi kimia (Subantari dan Prabowo, 2013). Tingginya bobot kering kecambah normal menunjukan tingginya kandungan cadangan makanan yang ada di dalam benih. Semakin tinggi bobot kering kecambah normal benih, semakin besar kandungan cadangan makanan dalam benihnya.

Ukuran benih yang besar menghasilkan bobot segar kecambah, bobot kering kecambah, dan bobot 1000 butir yang lebih tinggi dibandingkan dengan benih yang memiliki ukuran yang lebih kecil (Sadeghi dkk., 2011). Selain itu, lamanya periode simpan juga berpengaruh terhadap bobot kering kecambah jagung seperti halnya yang terjadi pada penelitian Koes dan Arief dkk. (2013) dimana lama periode simpan mempengaruhi bobot kering kecambah pada jagung varietas Srikandi Putih dan Anoman.

\section{Kesimpulan dan Saran}

Berdasarkan hasil penelitian, kesimpulan yang dapat diambil adalah sebagai berikut:

1. Terdapat perbedaan ketahanan simpan benih 16 genotip jagung pada dua periode simpan.

2. Genotip MDR 14.1.1 merupakan genotip yang memiliki ketahanan simpan terbaik pada parameter kadar air, daya hantar listrik, daya berkecambah, indeks vigor, keserempakan tumbuh, dan bobot kering kecambah normal

\section{Ucapan Terima Kasih}

Ucapan terima kasih disampaikan kepada DRPMI Unpad yang telah membiayai penelitian ini melalui Skema Penelitian Kompetensi Dosen Unpad Tahun Anggaran 2017 atas nama Anne Nuraini.

\section{Daftar Pustaka}

Ambika, S., V. Manonmani, and G. Somasundaram. 2014. Review on Effecr of Seed Size on Seedling Vigour and Seed Yield. Res. J. Seed.Sci7 (2): 31-38.

Azizah, E., A. Setyawan, M. Kadapi, Y. Yuwariah, dan D. Ruswandi. 2017.

Identifikasi morfologi dan agronomi jagung hibrida Unpad pada tumpangsari dengan padi hitam di dataran tinggi Arjasari Jawa Barat. Jurnal Kultivasi Vol. 16(1) Maret 2017. p : 260-264

Bewley, S.D. dan M. Black. 1978. Phisiology and Biochemistry of Seed. Springerverlag Heidelberg. New York. 302p.

Copeland, L. O. and M. B. McDonald. 2004. Principles of Seed Science and Technology. United States of America: Kluwer Academic Publisher.

Direktorat Perbenihan Tanaman Pangan. 2005. Evaluasi Kecambah: Pengujian Daya Berkecambah. Balai Pengembangan Mutu Benih Tanaman Pangan dan Hortikultura. Depok

Elia, A., M. Kadapi, Sumadi, dan D. Ruswandi. 2009. Identifikasi Mutu Fisik dan Fisiologis Benih Jagung Setelah Periode Simpan pada Berbagai Suhu dan Kelembaban. Zuriat, Vol. 20 No.1.

Heri Suryanto. 2013. Pengaruh beberapa perlakuan penyimpanan terhadap perkecambahan benih Suren (Toona sureni). Jurnal Penelitian Kehutanan Wallacea Vol. 2 No. 1 Apri 2013 : 26-40.

Hojjat, S.S. 2011. Effect of seed size on germination and seedling growth of some lentil genotypes. Int. J. Agric. Crop Sci., Vol. 3. : 1-5.

Justice. O. L and L. N. Bass. 2002. Prinsip dan Praktek Penyimpanan Benih (Terjemahan). PT. Raja Grafindo. Jakarta.

Kartahadimaja J., E. E. Syuriani, dan N. A. Hakim. 2013. Pengaruh Penyimpanan Jangka Panjang (Long Term) terhadap Viabilitas dan Vigor Empat Galur Benih Inbred Jagung. Jurnal Penelitian Terapan Vol. 13 (3) Hal: 168-173

Koes, F. dan R. Arief. 2010. Deteksi Dini Mutu dan Ketahanan Simpan Benih Jagung Hibrida F1 Bima 5 Melalui Uji Pengusangan Cepat (AAT). Prosiding Pekan Serealia Nasional. 
Kuswendi, V. Saputra, D. Siregar, dan A. Nurwida. 2009. Pengujian Faktor Periode Simpan, Kondisi Ruang, dan Media Penyimpanan terhadap Viabilitas Benih Jagung. Fakultas Pertanian Institut Pertanian Bogor.

Lesilolo, M. K., J. Riry, E. A. Matatula. 2013. Pengujian Viabilitas dan Vigor Benih Beberapa Jenis Tanaman yang Beredar di Pasaran Kota Ambon. Agrologia, Vol. 2 No.1 Hal 1-9.

Naning Yuniarti, Tati Suharti, Yulianti Bramasto. 2013. Pengaruh filtrat cendawan Aspergillus sp. dan Fusarium sp. terhadap viabilitas benih dan pertumbuhan bibit sengon. Jurnal Penelitian Kehutanan Wallacea Vol. 2 No. 2 Juni 2013 : 93-103

Pusat Data dan Sistem Informasi Pertanian. 2016. Outlook Komoditas Pertanian Sub Sektor Tanaman Pangan, Jagung. Kementerian Pertanian.

Rahmawati, A Ramlan dan S Saenong. 2005. Pengelolaan benih jagung. Dalam: Jagung: Hubungan Kualitas Benih (Vigor) dengan Produktivitas, 170-171. Balai Penelitian Tanaman Serealia Maros. Balitbangtan.

Sadjad, S. 1994. Kuantifikasi Metabolisme Benih. Gramedia. Jakarta. 145 hal.

Sadeghi, H., F. Khazaei, S. Sheidaei, and L. Yari. 2011. Effect of Seed Size on Seed Germination Behavior of Safflower (Carthamus tinctorius L.). ARPN Journal of Agricultural and Biological Science. VoL. 6, No. 4, April 2011 ISSN 1990-6145

Singgih Kurniawan, Ani Widiatuti, dan Y.M.S. Maryudani. 2008. Pengaruh perlakuan uap air panas dengan sistem pemanasan terbuka terhadap kesehatan dan viabilitas benih jagung. Jurnal Pelindungan Tanaman Indonesia Vol 14 No.2 : 63-69

Sigit, N., Sudaryano dan S. Lubis. 2005. Pengaruh Pengemasan terhadap Kandungan Oksigen (Oxygen Level) dan Perubahan Kualitas Gabah selama Penyimpanan. Prosiding Seminar Nasional Teknologi Inovatif Pascapanen untuk Pengembangan Industri Berbasis Pertanian. Balai Besar Penelitian dan
Pengembangan Pascapanen Pertanian.

Tatipata, A. Yudhoyono, P. Purwantoro, dan W. Magoendidjojo. 2004. Kajian Aspek Fisiologi dan Biokimia Deteriorasi Benih Kedelai dalam Penyimpanan. Ilmu Pertanian Vol. 11 No. 2, 2004: 76-87

Thahir, R. Sudaryono, Soemardi, dan Soemarhadi. 1988. Teknologi Pasca Panen Jagung. Dalam Subandi, M. Syam, dan Adi Widjono (Eds.). Jagung. Pusat Penelitian dan Pengembangan Tanaman Pangan. Badan Penelitian dan Pengembangan Pertanian. Bogor.

Titiksha. 2016. Germination of Seed: Types, Condition Required and Other Details. http:/ / www.biologydiscussion.com (Diakses pada tgl 3 Juni 2017)

Umar, S. 2012. Pengaruh Pemberian Bahan Organik terhadap Daya Simpan Benih Kedelai (Glycine max (L.) Merr.). Berita Biologi 11 (3), Desember 2012. Balai Penelitian Pertanian Lahan Rawa. Banjarbaru. p. 401-410.

Vieira, RD, AL. Penario, D. Perecin and M. Panobianco. 2002. Conductividade electrica e teor de agua inicial das sementes de soja (Electrical conductivity and initial water content of soybean seeds). Pesquisa Agropecuária Brasileira Brasília 37 (9): 1333-1338.

Widodo, A. A., A. Soegianto, dan A. N. Soegiharto. 2013. Kajian Evaluasi Mutu Benih Jaung Manis (Zea mays var. saccharata Sturt) dalam Penyimpanan pada berbagai Temperatur dan Kadar Air. Jurnal Agriekstensia. Vol 12 no. 1: 55-66.

Yuwariah, Y., D. Ruswandi, dan A.W. Irwan. 2017. Pengaruh pola tanam tumpangsari jagung dan kedelai terhadap pertumbuhan dan hasil jagung hibrida dan evaluasi tumpangsari di Arjasari Kabupaten Bandung. Jurnal Kultivasi Vol. 16 (3) Desember 2017

Zubachtirodin, Subandi, dan S. Saenong. 2005. Panduan Teknologi Produksi Jagung Bersari Bebas. Balai Penelitian Tanaman Serealia. Maros. 